\title{
www.czasopisma.pan.pl \\ Structural Analysis of the Selected Products From the Suspension Furnace Produced in the Internal Recycling
}

\author{
A.W. Bydałek ${ }^{\text {a, *, P. Schlafka a }}{ }^{\text {a K. Grządko a }}{ }^{\text {, W. Wołczyński }}{ }^{\text {b }}$, P. Kwapisiński ${ }^{\text {c }}$, \\ S. Bromber ${ }^{a}$, M. Wędrychowicz ${ }^{a}$ \\ ${ }^{a}$ University of Zielona Góra, Faculty of Mechanical Engineering, Podgórna 50, Zielona Góra, Poland \\ ${ }^{\mathrm{b}}$ Institute of Metallurgy and Materials PAN, Reymonta 25, 30-059 Kraków, Poland \\ ${ }^{c}$ Metallurgy Department, KGHM Polska Miedź S.A., M. Skłodowskiej-Curie 48, Lubin, Poland \\ *Corresponding author. E-mail address: adam_bk@poczta.onet.pl
}

Received 09.05.2016; accepted in revised form 12.10.2016

\begin{abstract}
There are presents the internal recycling in anode furnace, in addition to mainly blister copper and converter copper. During the process there arise the two types of semi-finished products intended for further pyro metallurgical processing: anode copper and anode slag. The stream of liquid blister copper enters into the anode furnace treatment, in which the losses are recovered, e.g. copper, resulting from oxidation and reduction of sulfides, oxides and the oxidation of metallic compounds of lead, zinc and iron. In the liquid phase there are still gaseous states, which gives the inverse relationship relating to the solid phase, wherein the gases found an outlet in waste gas or steam. The results of chemical analysis apparently differ from each other, because crystallite placement, the matrix structure and the presence of other phases and earth elements are not compared, which can be regained in the process of electrorefining. One should not interpret negatively smaller proportion of copper in the alloy, since during the later part of the production more elements can be obtained, for example from sludge, such as platinum group metals and lanthanides. According to the research the quality of blister copper, to a large extent, present in the alloy phase to many other elements, which can be recovered.
\end{abstract}

Keywords: Slag, Copper recovery, Recycling

\section{Introduction}

Anode furnaces are used in metallurgical processes for the fire refining of blister copper and converter copper [1]. During the process there arise the two types of semi-finished products intended for further pyro metallurgical processing: anode copper and anode slag. In addition to the essential characteristics of the technological process as maintaining the viscosity of the slag, atmosphere, and temperature $[3,4]$. It is necessary to analyze the composition of the charge, both in terms of its composition and rheological characteristics while moving in the furnace $[4,5]$.

Due to the need for the so-called internal recycling in anode furnace, in addition to mainly blister copper and converter copper, additional batch materials in the furnace are $[1,6]$ : waste from electrolytic refining process and own returns (foundry waste, improperly made anode and worn-out molds of anodes) - they have the same chemical composition as the anode, cascade copper (approx. 99.5\% Cu) - is a copper formed during the electrolyte purification, copper scrap - derived from external sources, is subject to continuous quality control, worn-out anode moulds. 
Further, not discussed in this paper products of the processes in the anode furnace, are anode slag and the process gas [10].

\section{Own Research}

\subsection{The chemical composition of blister copper}

Due to the mentioned at the outset the nature of melting in the recycling cycle of internal composition of the batches in subsequent melts is different. Only with regard to blister copper, there are three varieties from different processes and different chemical composition. The compositions of these variants are shown in Table 4.

\subsection{Structural analysis of blister copper}

Blister copper obtained at the inlet to the anode furnace was analyzed using optical microscopy and scanning microscopy. During the research on the chemical composition of samples of blister copper were subjected to evaluation of the 5 most characteristic areas.

Table 1

Averaged chemical composition of blister copper [9]

\begin{tabular}{|c|c|c|c|}
\hline \multirow[b]{2}{*}{$\begin{array}{c}\text { Element } \\
\text { (admixture in } \\
\text { the } \\
\text { composition) }\end{array}$} & \multicolumn{3}{|c|}{ The content of the composition [\%] } \\
\hline & $\begin{array}{l}\text { Blister } \\
\text { copper from } \\
\text { the flash } \\
\text { furnace }\end{array}$ & $\begin{array}{c}\text { Blister } \\
\text { copper from } \\
\text { converters } \\
\text { (an alloy of } \\
\mathrm{Cu}-\mathrm{Pb}-\mathrm{Fe})\end{array}$ & $\begin{array}{c}\text { Copper from } \\
\text { converters } \\
\text { (from copper } \\
\text { matte) }\end{array}$ \\
\hline $\mathrm{Cu}$ & 98,85 & 99 & 98,5 \\
\hline $\mathrm{Ag}$ & 0,28 & 0,13 & 0,2232 \\
\hline $\mathrm{S}$ & 0,17 & 0,003 & 0,011 \\
\hline $\mathrm{Pb}$ & 0,25 & 0,165 & 0,29 \\
\hline $\mathrm{Sb}$ & 0,0075 & 0,011 & 0,0163 \\
\hline $\mathrm{Sn}$ & 0,00015 & 0,0004 & 0,0012 \\
\hline $\mathrm{Bi}$ & 0,005 & 0,003 & 0,0005 \\
\hline As & 0,0985 & 0,529 & 0,2 \\
\hline $\mathrm{O}_{2}$ & 0,28 & 0,545 & 0,6 \\
\hline $\mathrm{Fe}$ & 0,03 & 0,0013 & 0,0053 \\
\hline $\mathrm{Ni}$ & 0,0215 & 0,111 & 0,15 \\
\hline $\mathrm{Zn}$ & 0,0015 & 0,00125 & 0,0025 \\
\hline
\end{tabular}

Analyzed surfaces shown in Figure 2 differ from one another, especially copper content and composition of metallic inclusions and oxides. Subsequently, in area 1 there is a large percentage of of blister copper composition and is the closest to the average values given in the literature (similar situation in zone 2). However, in the area of 3,4 and 5 percentage of blister copper significantly decreased for $\mathrm{Pb}$ inclusions (very bright areas) and oxide compounds (very dark areas).

Shown in Table 1 element content variation in the composition between the three copper they are mainly due to varying composition of the enriched ore from different mines, i.e. the quality of the smelting of the concentrates. On the other hand, the copper from the converters is dependent on the process, and the converter process of decoppering in an electric furnace as the alloy $\mathrm{Cu}-\mathrm{Fe}-\mathrm{Pb}$ results from the decoppering of slag suspension. In addition, blister copper is produced mainly from the copper matte in the shaft, which composition is the result of the quality of additives, the composition of the ore and time.

a)



b)



Fig. 1. Macrophotography of blister copper: a) at a magnification of $\mathrm{x} 250 \mathrm{~b}$ ) larger $\mathrm{x} 1500$

In the comparative analysis shown in Table 2 was subjected to region 1 (Fig. 2b), due to the highest possible percentage of blister copper composition, as well as average chemical composition indicated in the scientific literature. 
a)

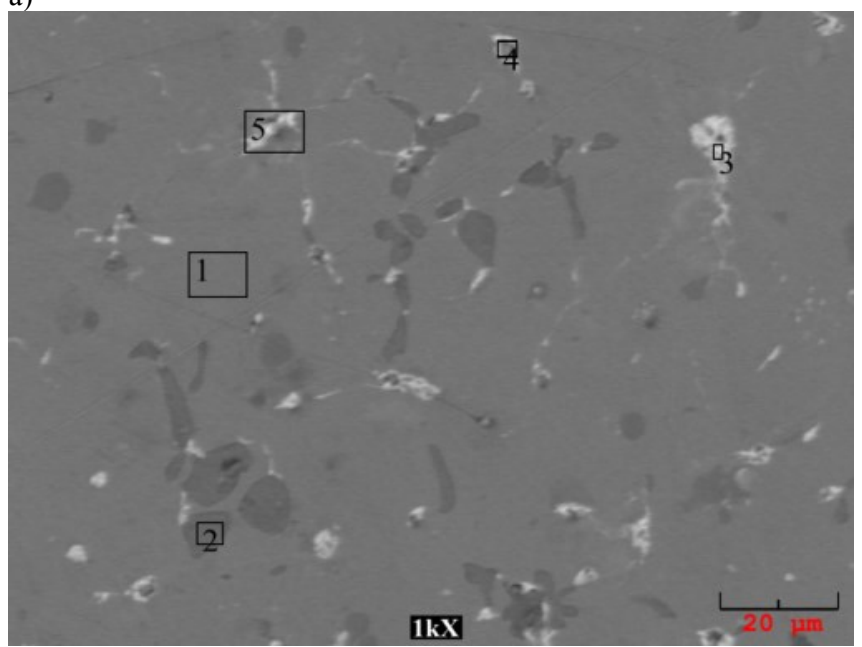

c)

fot 2 2s



e)

fot 2 -4s



b)

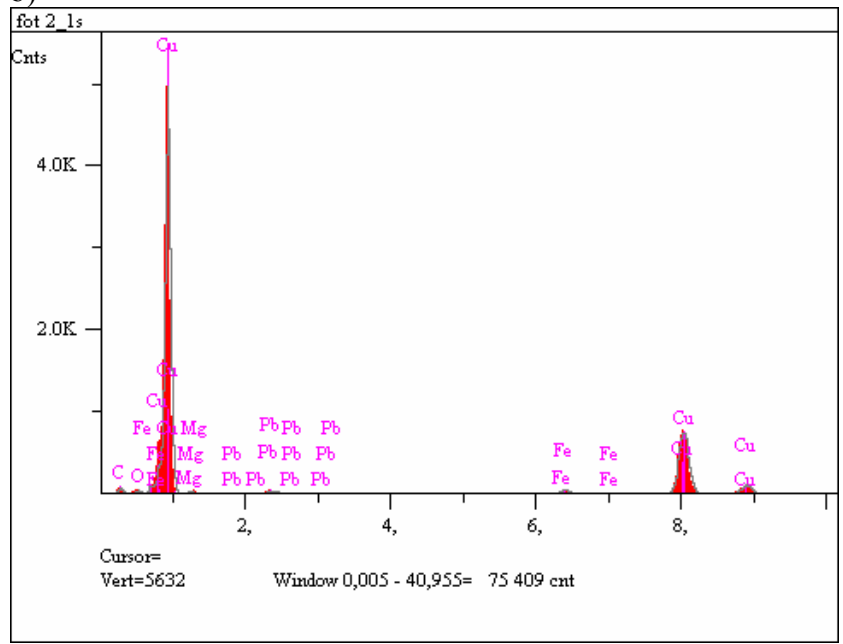

d)

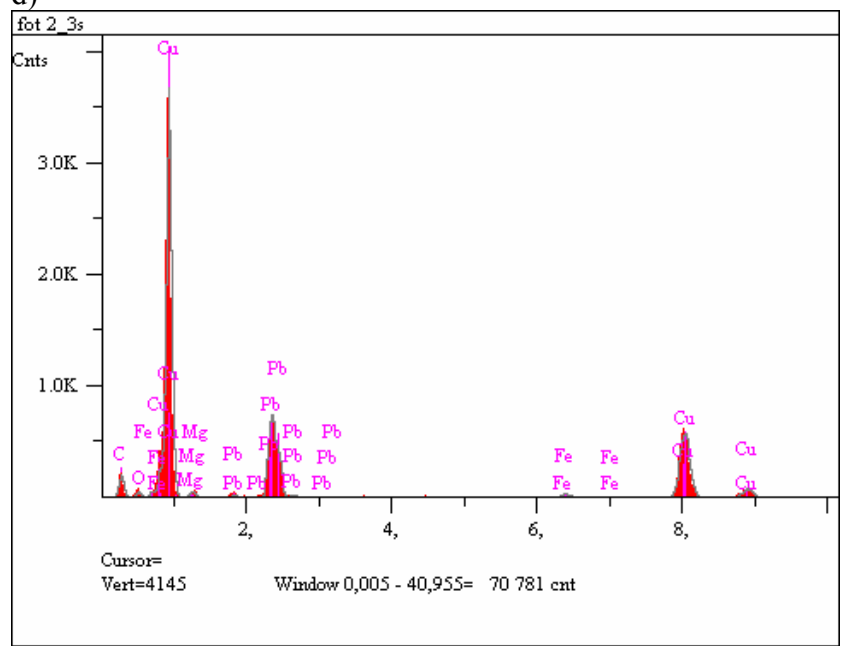

f)

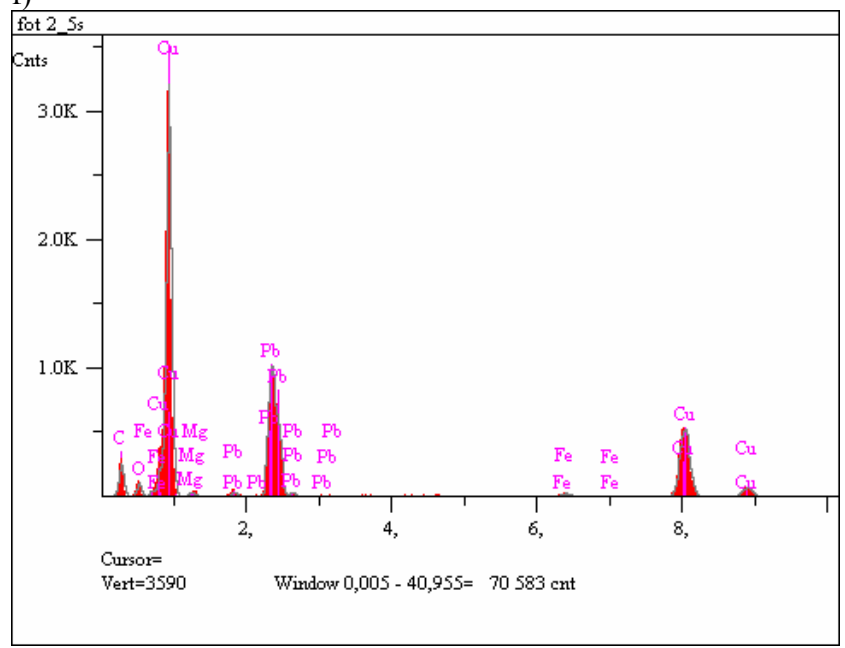

Fig. 2. a) Microphotograph of blister copper sample at a magnification x1000 with selected research areas of chemical composition, where: b) area 1, c) area 2, d) area 3 e) area 4, f) area of 5 
Table 2.

List compilation of the chemical composition of blister copper according to the average value reported in the literature, together with the value of the test results

\begin{tabular}{ccc}
\hline Element & $\begin{array}{c}\text { The percentage } \\
\text { resulting from } \\
\text { research }\end{array}$ & $\begin{array}{c}\text { The percentage resulting } \\
\text { from the publication, [...] }\end{array}$ \\
\hline $\mathrm{Cu}$ & 75,633 & 98,72 \\
\hline $\mathrm{Pb}$ & 5,089 & 0,3 \\
\hline $\mathrm{Fe}$ & 1,873 & 0,009 \\
\hline $\mathrm{C}$ & 14,044 & - \\
\hline $\mathrm{O}$ & 2,453 & - \\
\hline $\mathrm{Mg}$ & 0,907 & - \\
\hline $\mathrm{S}$ & - & 0,046 \\
\hline $\mathrm{Ag}$ & - & 0,258 \\
\hline $\mathrm{As}$ & - & 0,191 \\
\hline
\end{tabular}

\subsection{Structural analysis of slag anode}

The material of the anode slag was mounted and after sanding and polishing analyzed microscopically. Used for this purpose, optical and electron microscope $\_$scanning microscope (Fig. 3 and 4). Figure 5 presents the results of structural analysis of the slag from the anode with the distinction of phase components, while in Table 3 shows their chemical compositions.

a)

b)
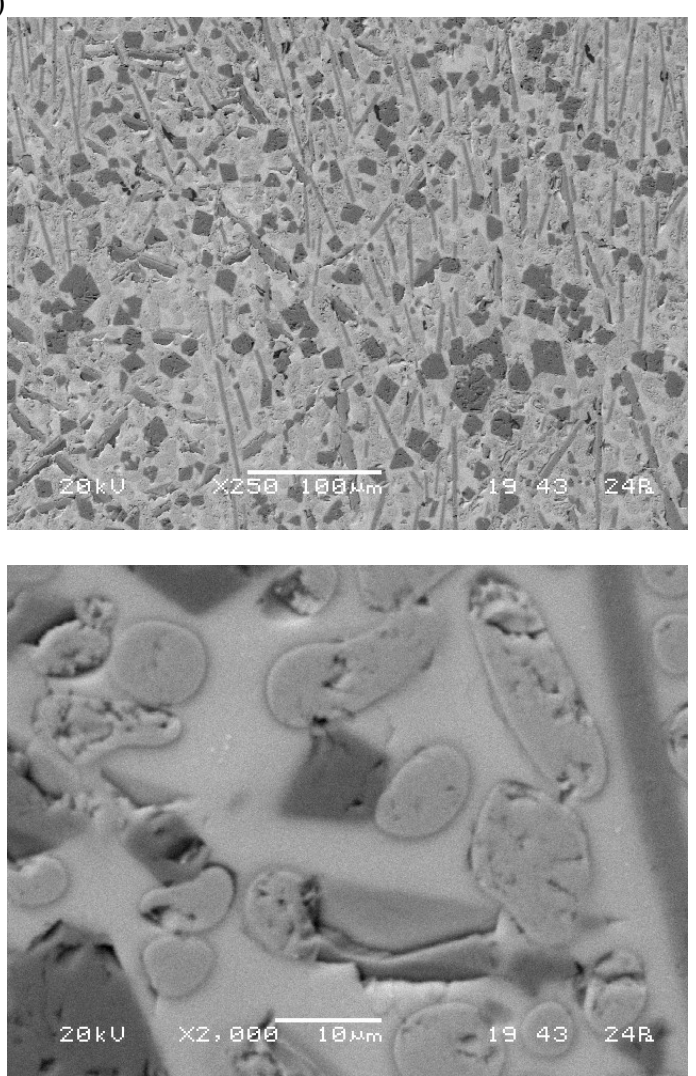

Fig. 3. Photographs of samples of slag anode made at a magnification of $\mathrm{x} 250$ (a) and $\mathrm{x} 2000(\mathrm{~b})$
Table 3 and 4 and Fig. 5 show that the area 1 lays in the separation with a shape similar to a circle, which diameter is approx. $20 \mu \mathrm{m}$. Iron prevails in the chemical composition of the separation. Its share is of $24.408 \%$ and a maximum content of this element in the anode slag from the anode furnace desktop should be equal to approx. $6 \%$. Separation marked as area 2 has a cross section of a rectangle with a length of approx. $40 \mu \mathrm{m}$ and a width of approx. $5 \mu \mathrm{m}$. In this area, and area 4 lead content was significantly exceeded compared to the one reported in the literature. These areas are approx. $6 \%$ of the admixture, while the standard is $2 \%$.

The chemical composition of the area 3 does not differ much from the standard composition. Only copper increased by more than $3 \%$ of the contents. This separation has a shape similar to an ellipse which at its widest point has a width of about $17 \mu \mathrm{m}$.

a)

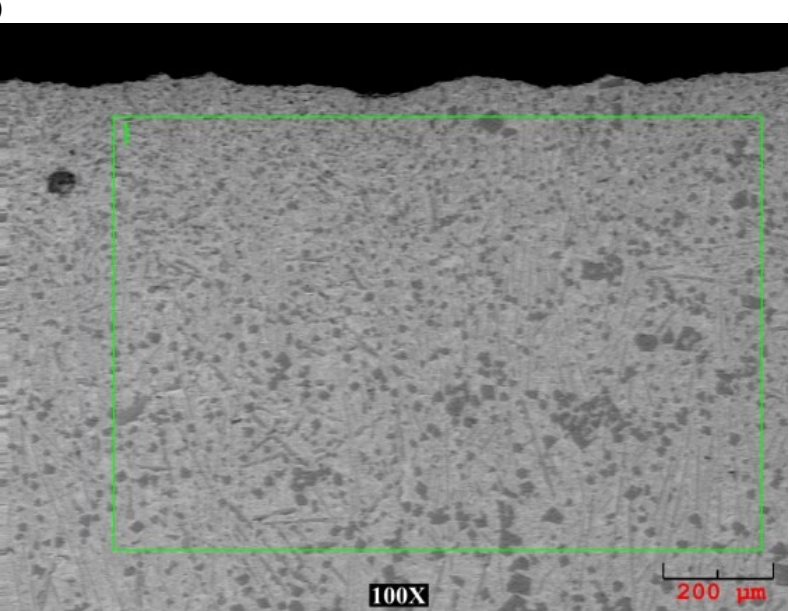

b)

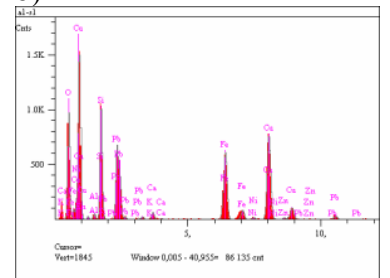

c)

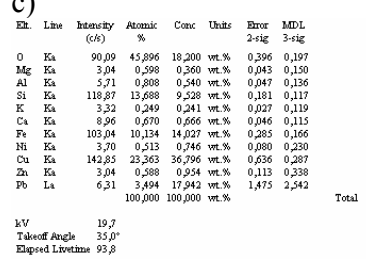

Fig. 4. a) Photography of a slag anode sample made at $x 100$ magnification of the selected area for the analysis of chemical composition by MRX, b) the energy spectrum of the analyzed area, c) the chemical composition of the analyzed area

Table 3.

The main constituent elements of the four areas of the slag anode sample

\begin{tabular}{ccccc}
\hline \multirow{2}{*}{ Element } & \multicolumn{4}{c}{ Content [\%] } \\
\cline { 2 - 5 } & Area no 1 & Area no 2 & Area no 3 & Area no 4 \\
\hline $\mathrm{Cu}$ & 9,057 & 14,392 & 50,579 & 10,606 \\
\hline $\mathrm{Pb}$ & 1,380 & 5,931 & 2,284 & 6,160 \\
\hline $\mathrm{Fe}$ & 24,408 & 8,245 & 3,703 & 5,989 \\
\hline $\mathrm{O}$ & 52,922 & 47,996 & 34,809 & 49,171 \\
\hline
\end{tabular}


a)

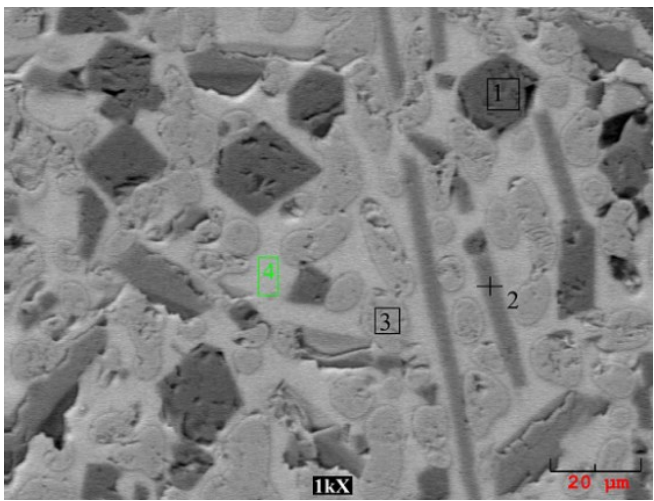

b)

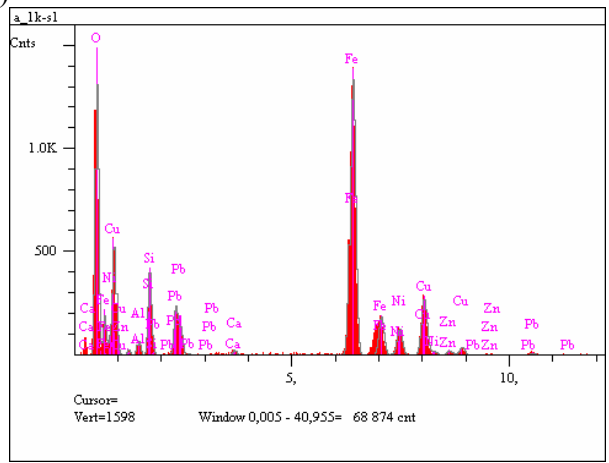

c)

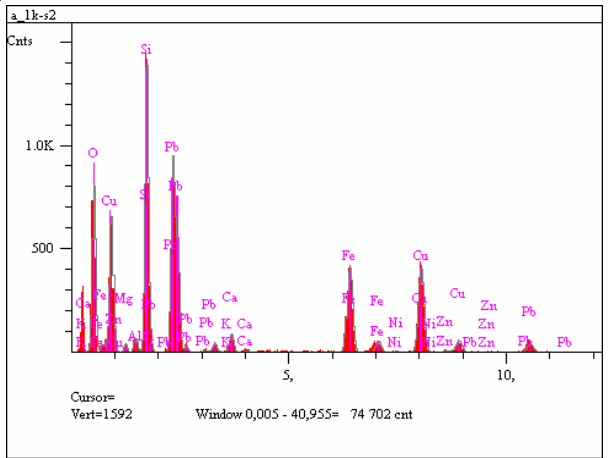

d)
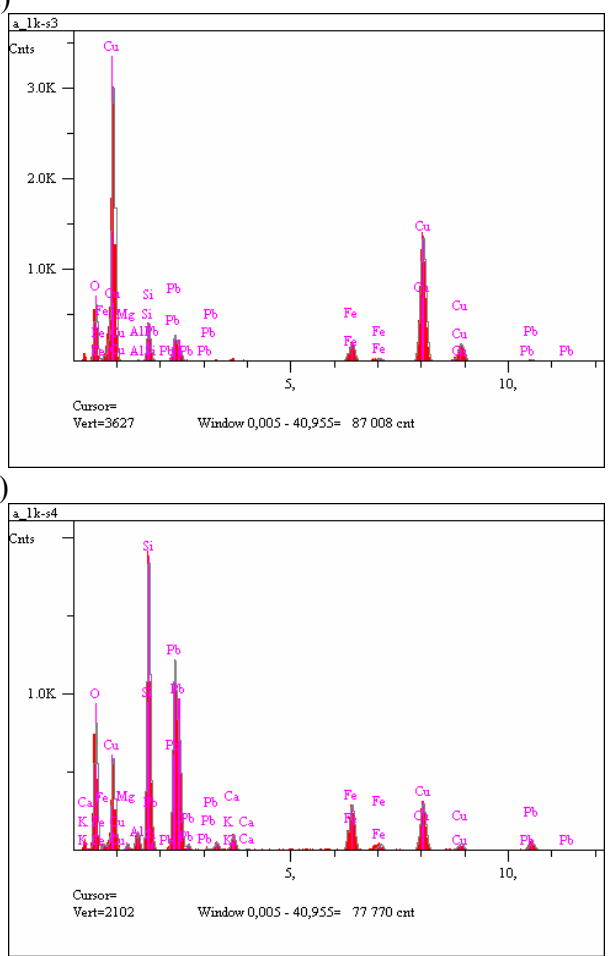

Fig. 5. a) Photography of slag anode samples made at x1000 magnification with four marked area for the analysis of chemical composition, b) area 1, c) area 2, d) area 3, e) area 4

Table 4 shows a comparison of the main constituent elements existing in the slag anode. This statement includes the value resulting from the analysis of structural and average value presented in the literature.

Table 4.

Comparison of key components of slag anode

\begin{tabular}{ccccc}
\hline Element & {$[10]$} & {$[11]$} & $\begin{array}{c}\text { Averaged value } \\
\text { from the } \\
\text { literature [\%] }\end{array}$ & $\begin{array}{c}\text { Value from } \\
\text { structural } \\
\text { studies [\%] }\end{array}$ \\
\hline $\mathrm{Cu}$ & $12-47$ & 25,6 & 29,5 & 23,363 \\
\hline $\mathrm{Pb}$ & $0,3-2$ & 1,7 & 2 & 3,494 \\
\hline $\mathrm{Fe}$ & $2-6$ & 2,5 & 4 & 10,134 \\
\hline
\end{tabular}

\section{Summary}

The stream of liquid blister copper enters into the anode furnace treatment, in which the losses are recovered, e.g. copper, resulting from oxidation and reduction of sulfides, oxides and the oxidation of metallic compounds of lead, zinc and iron. In the liquid phase there are still gaseous states, which gives the inverse relationship relating to the solid phase, wherein the gases found an outlet in waste gas or steam. The results of chemical analysis apparently differ from each other (Fig. 6), because crystallite placement, the matrix structure and the presence of other phases and earth elements are not compared, which can be regained in the process of electrorefining. One should not interpret negatively 
smaller proportion of copper in the alloy, since during the later part of the production more elements can be obtained, for example from sludge, such as platinum group metals and lanthanides. According to the research the quality of blister copper, to a large extent, present in the alloy phase to many other elements, which can be recovered.

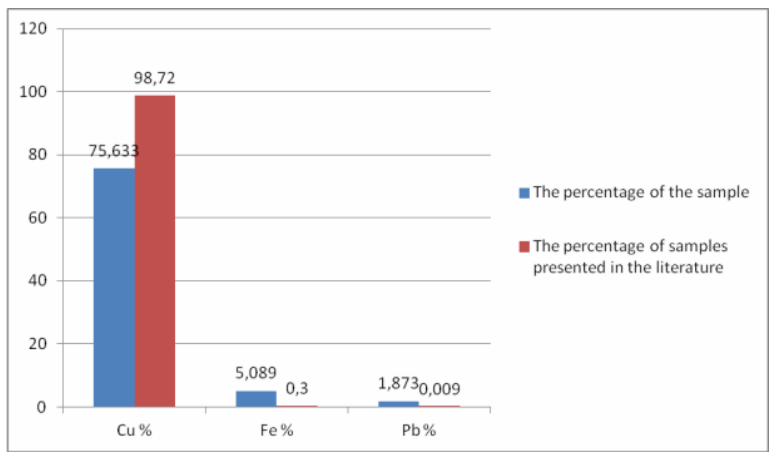

Fig. 6. Data selection of the chemical composition of blister copper samples and averaged chemical composition in the literature

Similar differences were observed in the composition of the slag anode (Figure 7). These differences in the content of elements can be caused by the fact that the charge of the anode furnace consists of three types of copper from individual processes and resulting from other components in the so-called own recycling.

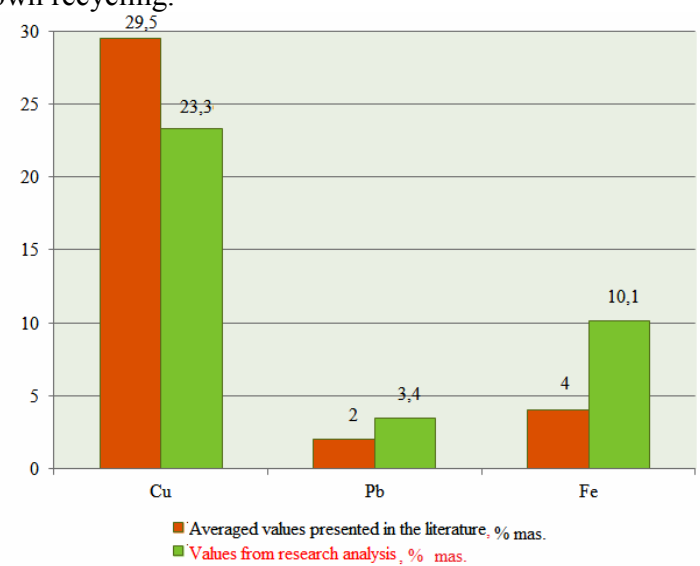

Fig. 7. Comparison of key components of anode slag

Composition of copper, the amount of impurities in the anode furnace, and thus also in the anode slag, depends on the composition and quality of the charge in the process, wherein the copper blister suspension, copper blister converters formed of a $\mathrm{Cu}-\mathrm{Fe}-\mathrm{Pb}$ alloy and converter copper produced from copper matte. The chemical composition of the material is also obtained from the use of technological processes including oxidation and reduction.

The quality of blister copper anode and slag resulting from the fire refining of copper have a decisive influence physicochemical processes running in the suspension furnace and shaft furnaces. However, since the stream has a diverse composition hence also created differences in the composition of slag. This becomes particularly clear in the microstructure, which is caused by the formation of heterogeneous phases.

\section{Acknowledgements}

This project was supported by the National Center for Research and Development under Grant No. PBS3/A5/45/2015 (PBS3/244 864/PP/MMB).

\section{Reference}

[1] Karwan, T. (2013). Metallurgy Non-Ferrous Metals. Kraków - Bukowno. (in Polish).

[2] Migas, P. \& Karbowniczek, M. (2010). Interactions between liquid slag and graphite during the reduction of metallic oxides. Arch. Metall. Mater. 55(4), 1147-1157,

[3] Bydałek, A.W., Bydałek, A., Wołczyński, W. \& Biernat, S. (2015). The concept for the process of slag decopperisation in the flash furnace process use the complex reagents. Arch. Metall. Mater. 60(1), 323-326.

[4] Łedzki, A., Migas, P., Stachura, R., Klimczyk, A. \& Bernasowski, M. (2009). Chemical and phase characteristic of titanium compounds produced in iron blast furnace dripping zone. Arch. Metall. Mater. 54(1), 129-135.

[5] Wołczyński, W., Guzik, E., Wajda, W., Jędrzejczyk, D., Kania, B. \& Kostrzewa, M. (2012). CET in Solidifying Roll - Thermal Gradient Field Analysis. Arch. Metall. Mater. 57, 105-117.

[6] Kucharski, M. (2003). Pyrometallurgy copper. Kraków: Wyd. AGH. (in Polish).

[7] KGHM Polska Miedź S.A. from (2016 march), http://www.kghm.pl/index.dhtml?category_id $=272$

[8] Włodarczyk, M. (2010). The process of fire refining of copper in the technological Copper Smelter Głogów II - the use of different types of reducer on the technological development. Kraków: Wyd. AGH. (in Polish).

[9] Chmielarz, A., Czernecki, J., Zakrzewski, J., Bratek, S., Sobierajski, S., Wojtowicz, J., Romanowicz, P., Krukowski, T. (1986). P. 238310 Pat. PRL.

[10] Bydałek, A.W., Biernat, S., Bydałek, A. \& Schlafka, P. (2014). The innovative analysis of the refinement ability exstractive slag. International Journal of Engineering and Innovative Technology (IJEIT). 4(5), 186-193. ISSN:22773754 . 